\title{
A posztháborús pillanat „hosszú expozíciója”. A boszniai háború utóhatásainak tér- és fotóelméleti megközelítése
}

\begin{abstract}
Absztrakt
A tanulmány az In The Shadow of War (2014) címú film elemzésén keresztül a posztháborús állapot dokumentumfilmes reprezentációjával és a trauma problémájának vizuális és filmnyelvi szempontjával foglalkozik. A szöveg központi állítása, hogy e dokumentumfilm temporalitása analóg a szereplôk idôpercepciójával: habár a délszláv háború hivatalosan befejezôdött, az ott élók számára korántsem zárult le, mintegy a „posztháborús jelenben”, a háború kitágított, végtelenített és állandósult pillanatában élnek. E mozdulatlan, bénult állapotot a szöveg részben a hezitáció, részben pedig a heterotópia koncepciója felól vizsgálja meg, majd pedig a keret mint fotóelméleti probléma szempontjából elemzi azt.

\section{Szerzó}

Simor Kamilla a PTE BTK Irodalomtudományi Doktori Iskola elsőéves hallgatója, a Magyar Filmtudományi Társaság és a Kerényi Károly Szakkollégium tagja. Kutatásában a performatív dokumentumfilmek múfajelméleti, narratológiai és politikai esztétika felőli megközelítésével foglalkozik.

E-mail: kamillasimor@gmail.com
\end{abstract}

https://doi.org/10.31176/apertura.2019.15.3.4 


\title{
Simor Kamilla
}

\section{A posztháborús pillanat „hosszú expozíciója”. A boszniai háború utóhatásainak tér- és fotóelméleti megközelítése}

\author{
A fotográfia (...) a halálról szól jövô idóben. ${ }^{[1]}$ \\ (Roland Barthes)
}

Tanulmányomban a boszniai háború utóéletének dokumentumfilmes reprezentációjával foglalkozom az In The Shadow of War (2014) címú alkotás elemzésén keresztül. A Georgia és Sophia Scott által rendezett film középpontjában négy boszniai fiatal áll, akik mind a BoszniaHercegovinát érintố délszláv konfliktus lezárulása idején születtek. Habár Magdalena, Ilija, Ante és Elvis közvetlenül nem tapasztalták meg a háborút, de közvetetten, szüleiken keresztül egész életükre hatással van: az árvaság, a háborús bûnökért börtönben ülô vagy a poszttraumás stressz szindrómában szenvedô apától való rettegés és a saját fiát megtagadó anya határozzák meg a fiatalok mindennapjait.

„Boszniában a háború alatt vagy után született gyerekek egy elveszett generációhoz tartoznak. Ez a háború következménye.” A filmben megszólaló nevelôotthon vezetôjének gondolatai képezték vizsgálatom alapját, amelynek fókuszában az a kérdés állt, hogy miként reprezentálódik vizuális és narratív síkon egy több mint két évtizede lezárult háború a jelen kontextusában. Elemzésemben a különbözô valóságértelmezések párhuzamos jelenlétét, illetve azok képi megjelenítését tematizálom, majd pedig ezek több szinten manifesztálódó ellentmondásait, konfliktusait bontom ki. Állításom, hogy a dokumentumfilm temporalitása analóg a szereplôk idôpercepciójával: habár a háború hivatalosan befejeződött, az ott élők számára korántsem zárult le, mintegy a „posztháborús jelenben”, a háború kitágított, végtelenített és állandósult pillanatában élnek. E stagnáló, mozdulatlan állapotot fotóelméleti szempontból közelítem meg annak érdekében, hogy a feldolgozatlan és az ábrázolhatatlan trauma problémáját vizuális és filmnyelvi szempontból megközelíthetốbbé tegyem.

\section{Heterotóp terek és állandósult konfliktusok - A párhuzamos valóságértelmezések bénító hatása}

A film legfontosabb helyszínei négy boszniai város, Medjugorje, Mostar, Zenica és Szarajevó. Az e terekrôl készült, nagyrészt csendéletszerú, mozdulatlan képsorok mintegy albumként, gyưjteményként is funkcionálnak a háború utáni balkáni országról. A rendezók igyekeznek mind apró részleteiben, mind pedig totalitásában megmutatni Bosznia-Hercegovinát, ám az összkép 
mégis töredékes lesz. Úgy vélem, e fragmentáltságnak nem technikai vagy erőforrásbeli okai vannak: a hiány érzete sokkal inkább átvitt értelemben, a konkrét anyagi környezettôl elszakadva manifesztálódik. Meglátásom szerint a film jeleneteinek meghatározó része a háború utáni balkáni életrốl nem leíró vagy dokumentációs jelleggel bír, mivel a térrel kapcsolatos tényszerú megjelenítés a szimbolikus, metaforikus jelentésmezôbe lép át. E problémát, illetve a térben keletkező, a teret és a szereplôk életét meghatározó hiány kérdését két fogalom, a heterotópia és a hezitáció segítségével vizsgálom meg.

Michel Foucault a Más terekrốl címú munkájában heterotópiának nevezi azokat az „ellenhelyszíneket”, amelyek, habár az aktuális világban jól behatárolhatók, mégis kívül esnek minden helyen, és az utópiákkal állíthatók szembe. Fontos, hogy anyagi meglétük mellett mindig valamilyen irreálisra, nem jelenlévőre nyitnak, mutatnak rá: „helyek, melyek abszolút módon "mások «, mint mindazon helyszínek, melyekre reflektálnak”. ${ }^{[2]}$ A filozófus a heterotópiák hat különféle jellemzőjét különíti el, számunkra pedig most a harmadik és a negyedik alapelv lesz különösen meghatározó. Az előbbi szerint „a heterotópiának hatalmában áll ütköztetni több teret egyetlen valós helyen, több olyan helyszínt, melyek önmagukban inkompatibilisek." ${ }^{[3]}$ Foucault a színház és a mozi példáját említi, amely általában négyszögletes, zárt kerete ellenére képes különböző, egymástól alapvetően idegen helyet keverni, felsorakoztatni. A negyedik alapelv a heterokrónia problémáját tematizálja, amely az „idô vágásaihoz” köthetô és a heterotópiával szorosan összefüggô jelenség: „a heterotópia akkor kerül ereje teljébe, amikor az emberek valami abszolút törést szenvednek el a hagyományos idejükkel." [4]

Az In The Shadow of War valós és képzeletbeli tereinek bemutatásakor több szinten is megfigyelhetố konfliktus alakul ki, amely szorosan kötôdik a heterokrónia fogalma által megragadott „idővágás” vagy idôbeli törés eseményeihez. Ez két részre osztja a filmbéli idôpercepciót: háború előtti és háború utáni idôszakra. Az első, leginkább materiális, kézzelfogható szinthez azokat a térábrázolásokat sorolom, amelyek egy beállításon belül kétféle korszakot rendelnek egymás mellé; jó példa erre a szarajevói út során készített felvételsorozat: a lyukacsosra bombázott házak mögött már új, parabolaantennákkal felszerelt, modern panelek állnak. Hasonlóan ide sorolható az a jelenet is, amelyen Ilija ugrása látható: az emblematikus, újraépített boszniai Öreg híd mintegy a háború áldozataként magasodik a háború tetốpontján született fiú fölé. 


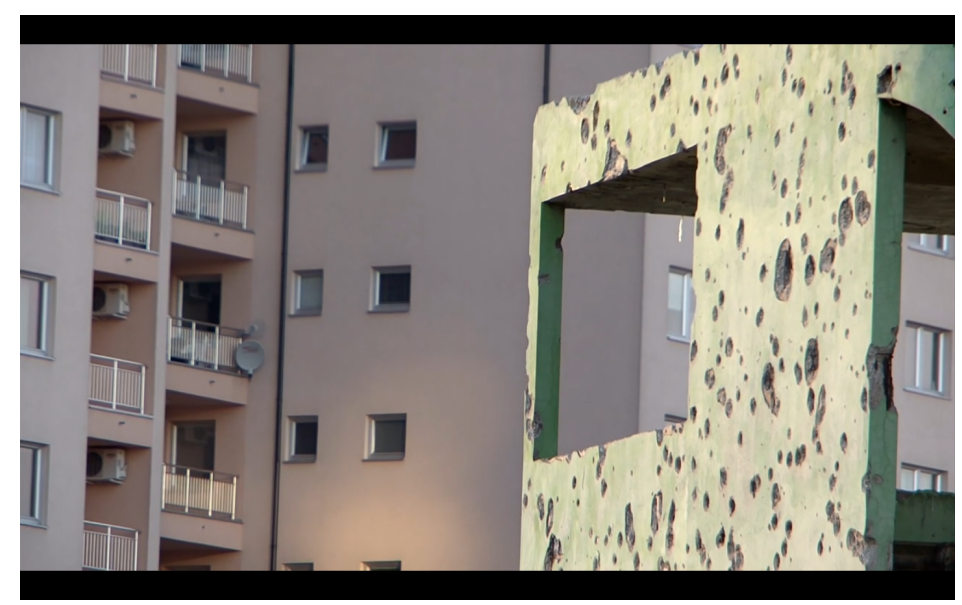

Szarajevói látkép a lebombázott és az újonnan felhúzott épületekkel.

In The Shadow of War (Georgia Scott-Sophia Scott, 2014)



Ilija ugrása az évente megrendezett versenyen. In The Shadow of

War (Georgia Scott-Sophia Scott, 2014)

A második szint ennél összetettebb és metaforikusabb: a filmben a négy városról készült felvételek egymás mellé rendeződnek, premier plánokban a legapróbb részleteket, nagytotálokban pedig az adott várost látjuk madárperspektívából. E beállításokat a film utómunkája során egymás mellé vágják, ez az eljárás pedig tematikai szempontból hasonlít a városi fotóalbumokéra: a gyújteményben a terek egymás mellé rendeződnek, a felvétel pillanatában azonban még csak lehetséges, nem rögzített konfigurációkról van szó. ${ }^{[5]}$ Bizonyos megközelítésben a fotóalbum is értelmezhetô heterotópiaként, amely egyszerre képes önmagán kívül „eltérô” helyekre referálni. Kiss Noémi interpretációjában a fényképgyújteményben az adott korszak „egy sajátos formavilágként reprezentálódik: a részletekből, kereszteződésekből, telefonhálózatokból” jön létre a város. Fontos, hogy az album minden egyes darabja nem önmagában, hanem kontextusban áll, továbbá „a látszólagos távolság leszűkül és egymás mellé kerülnek egymástól kilométer távolságban lévố terek, összepasszírozódnak egymástól radikálisan különbözô tárgyak” ${ }^{[6]} \mathrm{Az}$ In The Shadow of War esetében azonban ebben az értelemben mintha mégsem beszélhetnénk hagyományos, totalitásra törekvố gyújteményrôl: a film betekintést nyújt a háború utáni boszniai városok jelenbeli állapotába, ám azt a maga fragmentáltságában ragadja meg. Kisebb-nagyobb töredékek formájában férünk hozzá a délszláv területhez, s mintha éppen ebben rejlene lényegi 
mibenléte: a rések és a hiányok szervezik a filmi teret.

A harmadik szint verbális jellegú, a beszédben, a szereplôk monológjaiban manifesztálódik: ez az utópiák szintje. Foucault a heterotópiákkal szemben utópiának nevezi azokat az irreális tereket, amelyeknek nincs valós helye, amely a „a társadalmat tökéletesített formában, vagy önmaga ellentéteként" mutatja. A filmben utópikusnak nevezem azokat a jeleneteket, amikor a négy szereplő olyan képzeletbeli, alternatív világokról beszél, amelyekben el tudnák képzelni, hogy normális életük lehessen: Elvis halott édesanyját támasztaná fel, Ilija győztes sportolóként várna elismerést az ốt megtagadó édesanyjától, Ante katonaként harcolna börtönből szabadult édesapja mellett, Magdalena pedig egy olyan apára vágyik, aki sosem járta meg a délszláv háborút. A fiatalok elképzelései gyökeres ellentétben állnak azzal a valósággal, amelyben élnek: kívánságaik megmaradnak a reménytelen vágyakozás szintjén. Az ezen a szinten keletkezô hiányt még inkább elmélyítik a film záróképei, amelyekból értesülünk a négy fiatal késôbbi sikertelen próbálkozásairól.

Az utópiák jelenléte mellett érdemes a jelen értelmezési kísérleteirôl is beszélni. Véleményem szerint a szereplôk irreálisnak tûnô vágyai a helyzetükre való reflexió hiányából, képtelenségéből fakadhatnak, azaz nem tudják megragadni azokat a problémákat, amelyek determinálják mindennapjaikat. Michel Foucault szerint ahhoz, hogy a jelent el tudjuk gondolni, elóbb el kell határolódnunk magától a jelentôl, illetve a múlttól is abban az értelemben, hogy a kettő között ne feltételezzünk kontinuitást, vagyis - Takács Ádám interpretációjában - a megélt jelenünk történelmi meghatározottságának megértéséhez elôször a múltat kell elgondolnunk.

A jelent, melyben élünk, csak a jelen gondolása révén tehetjük áttetszóvé, ám ez a feladat csak a múlt elgondolása segítségével lehet sikeres. A jelen a múlt gondolása révén megnyílik, és ez lehetôséget teremt egy kritikai távolság létrehozására, s ezáltal a jelen kritikai analízisére. Foucault szerint a »jelen története« egyetlen mondatban összefoglalva ezt jelenti: elgondolni a jelent a múlt közvetítésével a jelen ellenében. [...] Ez a lépés arra szolgál, hogy a gondolkodás megkíséreljen láthatóvá tenni olyan szabályszerúségeket, melyek meghatározzák jelenünket, ám melyek onnan közvetlenül nem láthatóak. ${ }^{[7]}$

Ha tehát ebben az értelemben használjuk a megélt jelen és a gondolt jelen kifejezéseket, máris megragadhatóbbá válik az ezen a szinten keletkezô hiány jellege: mivel a megélt jelenben a szereplóknek nincsenek eszközeik arra, hogy reflexíven viszonyulhassanak a múlt történéseire, így a jelen elgondolását sem tudják kivitelezni vagy ahhoz kritikusan közelíteni.

A mindhárom szinten megfigyelhetô szembenállás, konfliktus a film során azonban nem oldódik fel, hanem egyre inkább növekszik. Ezen ambivalenciák hipotézisem szerint megtorpanásként, stagnálásként, a mobilitás hiányaként érzékelhetốk, és a hezitáció koncepciója felôl ragadhatók meg. Strausz László a román újhullám fikciós filmjeire alkalmazza elméletét, ám a hezitáció mint szociális-politikai-múvészeti attitűd meghatározó az általam vizsgált dokumentumfilmmel kapcsolatban is. Azért tartom relevánsnak e koncepció használatát, mert az In The Shadow of War 
ban a legtöbb esetben - az új román filmekhez hasonlóan - egymásnak ellentmondó, párhuzamos diskurzusok sokaságával találkozhatunk: a film két rendezôje felismerte, hogy a múlt aligha rögzíthetô, ezért ehelyett egymással sokszor ellentétes valóságértelmezéseket ütköztetnek a szereplôk által. A hezitáció mint szövegkonstrukciós stratégia

egy mozgásban lévő értelmezői pozíciót jelöl ki a nézó számára. [...] Ez egy, a kulturális emlékezet folyamataihoz kapcsolódó elemzési stratégia, amely a társadalmi valóságnak (távolabbi múltnak, illetve a Kelet-Európában gyakran traumatikus közelmúltnak) a jelen számára feltáruló lehetôségei, eltérô verziói közötti oszcilláló mozgására hivatott utalni. Az emlékezet határozatlanságára, befejezetlenségére és performativitására utal, hiszen a múlt és a jelen eltérô magyarázatainak különbségeit, illetve azok konstruáltságát helyezi elốtérbe. ${ }^{[8]}$

Elemzésemben kevésbé a néző értelmezôi, reflexiós tevékenységére fókuszálok, mint inkább az ellentétes valóságértelmezések által kialakult konfliktusokra és megtorpanásokra.

Lényeges különbség a Strausz által tárgyalt román filmek és az itt elemzett alkotás között, hogy az In The Shadow of War kitágítja a hezitáció, a különböző valóságértelmezések ütközésének pillanatát, és úgy gondolom, kimerevíti ezt a pillanatot. Fontos, hogy a szereplôk megállapításai, kijelentései nem csupán a (közel)múltra, hanem a legtöbb esetben a filmi jelenre vonatkoznak. Mivel a megélt jelen ellentmondásos elbeszéléseirôl van szó, ezért nem egyszerúen a megtörtént események különbözô megközelítéseirôl beszélhetünk. (Ennek talán legjobb példája Magdalena és apja, Predag kapcsolata: míg a férfi magát becsületes, háborúban megedzett embernek tartja, addig lánya szerint agresszív és félelmetes szülô, akitôl ezért több alkalommal is elmenekült.)

Jóllehet háború utáni állapotról beszélünk, a film azt az érzést kelti, mintha a háború lezárulásával a végtelenbe kimerevített posztháborús jelen venné kezdetét, amelyben - habár apróbb mozgások megfigyelhetôk - mintha valóban megállt volna az élet. Nem csupán a történet szintjén a szereplôk újra és újra ismétlődô és kudarcba fulladó kitörési kísérletei erôsítik fel az egy helyben toporgás érzetét, hanem az elsốre stilisztikainak tûnô, az elóbbiekben is elemzett térbeli ábrázolások is: emberek nélküli, kietlen városi tájak, amelyekben semmilyen mozgás nem látható. Ha követjük Michel de Certeau megállapításait, miszerint „a teret valamiképpen a benne zajló mozgások keltik életre", ${ }^{[9]}$ illetve Fredric Jameson téziseit a tér és a hely kategóriáinak elkülönítésével, valamint a degradált térrel ${ }^{[10]}$ kapcsolatban, akkor a mozgás, a szituativitás és az esemény hiányában e felvételekre állóképként is tekinthetünk, „hiány artikulálta képiségként”.[11] Tanulmányom második felében fotóelméleti szempontból közelítem meg e kimerevített és végtelenített pillanatot, ezzel összefüggésben pedig a háborús trauma, illetve a trauma feldolgozhatóságának kérdését.

\section{Végtelenített pillanatok, fényképszerú élethelyzetek - A trauma okozta}




\section{stagnálás fotóelméleti lehetôségeiról}

André Bazin máig nagy hatású, a fénykép ontológiájáról írt tanulmányában az „idő bebalzsamozásaként" utal a fotóra, amely a pillanatot ki tudja ragadni az idô múlásából. ${ }^{[12]} \mathrm{A}$ következôkben a fotóelméleti megközelítést szigorúan esztétikai-filozófiai, tehát nem technikai értelemben használom: az érdekel, hogy a trauma okozta stagnálás, megtorpanás miként válik elemezhetôbbé, illetve hozzáférhetôbbé ezen aspektus felôl. E probléma megragadhatóságát elsôsorban a keret koncepciója felól kísérlem meg. Bazin a keret mint határ kérdését a festmény és a film ontológiájának kapcsán elemzi. „A kép kerete a tér megtörésének zónáját hozza létre. A külsô széleit szegélyezố természetes és tapasztalati térrel a befelé terjedô teret helyezi szembe, a szemlélődés terét, mely csak a kép belseje felé nyitott. A mozivászon határai [...] nem képkeret, hanem pusztán olyan »takarólapot« képviselnek, mely csak a valóság egy részét tudja elfedni. [...] A keret centripetális, a mozivászon centrifugális." [13]

Bazin meglátásait felhasználva Roland Barthes a film esetében olyan vak mezórôl ír, amely a vászon határain kívül található, s a nézó azt feltételezi, hogy a szereplôk ott élik tovább az életüket akkor is, mikor éppen nincsenek a színen - tehát mozgásban vannak az adott jeleneten kívül is. „[A] filmben van egy olyan lehetôség, ami a Fotográfiában első látásra nincs meg: a vászon nem keret, hanem maszk, takaró; az a szereplô, aki éppen kimegy a képbôl, továbbra is él, a részleges látványhoz állandóan egy mögöttes, »vak mező« kapcsolódik."[14] Barthes megkülönbözteti a studium és a punctum-szerú fényképeket: míg az elsố inkább dokumentációs, leíró, tényrögzítô jellegú, és nem mutat túl a kereten, addig az utóbbira az jellemzô, hogy egy olyan apró, „mezốn kívüli mozzanatot" tartalmaz, amely kizökkenti a nézôt, fellebbenti a kereten túli világ létét és kilépteti figuráit a vak térbe. Elemzésem szempontjából az elsô, studium-szerú képek meghatározása lesz releváns, amelyekról Barthes a következôket írja: „Minden, ami a kereten belül történik, teljesen elenyészik, mihelyt kilép a keretból. Amikor a Fényképet mozdulatlan képként határozzák meg, ez nemcsak azt jelenti, hogy a személyek, akiket ábrázol, nem mozognak, hanem azt is, hogy nem tudnak kilépni a képból, olyanok, mint az elbódított, gombostúre szúrt pillangók egy gyújteményben."[15]

A keret koncepcióját tehát nem csupán technikai, materiális értelemben használom, hanem metaforikusan: miként értelmezhetô ez a lehatároltság a film terében és a szereplôk életében, illetve hogyan közelíthetốk meg a különbözô „kompozíciók”. Az elôbbiekben elemzett mozdulatlanság így jelen van az emberi alakok nélküli városterek bemutatásakor, a keretfunkció viszont inkább a narratíva szintjén meghatározó. Mind a négy szereplô törekszik arra, hogy kitörjön bénult helyzetéból, ám mindnyájan - próbálkozások sorát végrehajtva - visszaérnek kiinduló helyzetükhöz, s a kör bezárul: Elvis Szarajevót megjárva hazatér és az utcára kerül, Magdalena a nevelőotthont elhagyva Horvátországba menekül, ahonnan viszont haza kell térnie, Ilija a sikertelen verseny után ismét edzeni kezd, Ante pedig katonának készül. Utóbbi fiú az egyetlen, aki elsőre úgy tủnik, nem körbe-körbe jár, hiszen már a film elejétôl kezdve a katonaságra összpontosított és edzett. Ám ha figyelembe vesszük Ante múltját és felmenôit, illetve 
nagybátyja aggodalmaskodó megjegyzéseit azzal kapcsolatban, hogy a fiú apja sorsára fog jutni (a férfit 2004-ben a hágai Nemzetközi Bíróság húsz év börtönre ítélte háborús bûnei miatt), máris hasonló körpályán kezd el mozogni ő is, mint a film további három szereplôje. A kiinduló és végpont közti állandó oda-vissza csapódás eredményezi a keret-szimbolika megerôsödését: úgy tûnik, mintha a négy fiatal csak e határokon belül tudná élni mindennapjait. A körkörösség és az ebból fakadó céltalanság egyik legérzékletesebb jelenete az, amikor Elvis vonatra száll, és egy jobb élet reményében Szarajevó felé tart. De már a fülkében - mikor még el sem érte úti célját - így nyilatkozik terveiről: „Szarajevóba tartok, mert nincsen semmim, úgyhogy lopok némi pénzt, hogy aztán tovább mehessek. Addig fogok lopni, amíg el nem kapnak - és ha elkapnak, kit érdekel?" Vizuális szempontból és a történet szintjén ugyancsak kifejező az a rész, amelyben Ilija válla megrándul a hídugró versenyen, és fel kell adnia álmát. Mostar hídjának lerombolása a háború különösen meghatározó képe - az újjáépített hídról való leugrás és sérülés metaforikus értelmezése is az elóbbiekben elemzett idôkeret megszilárdítását erôsíti.

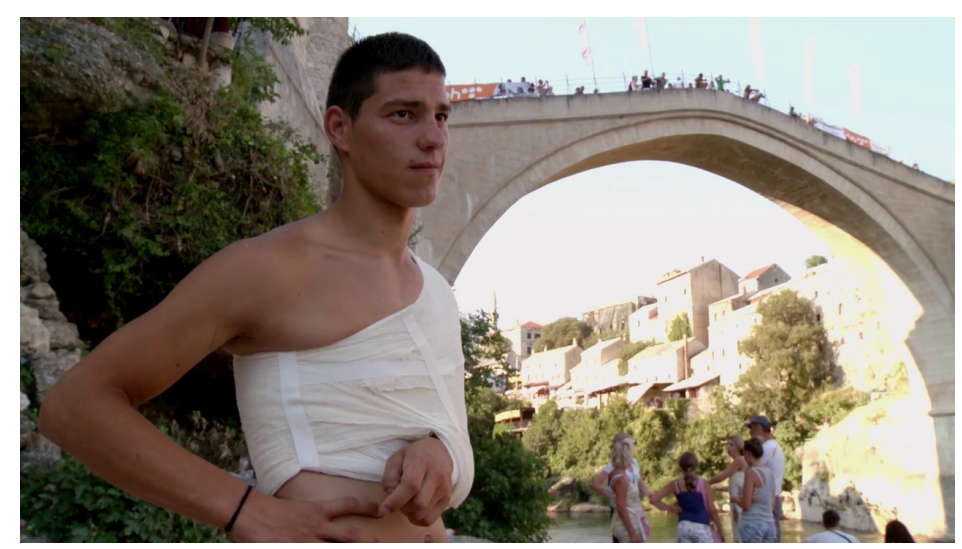

In The Shadow of War (Georgia Scott-Sophia Scott 2014)

A „bebalzsamozott idô” kifejezés különösen találó a filmi temporalitás jellemzésére: az In The Shadow of War esetében szinte semmilyen kapaszkodót vagy külsố támpontot nem kapunk az idô múlásának pontos meghatározásához, a feliratok csupán a helyszínek váltakozását jelölik. Ha Ilija a kezdô jelenetek egyikében nem említi meg, hogy öt hónapja van felkészülni a versenyre, feltehetôen a nézô igen tanácstalan volna, pontosan mennyi idô is telt el a film kezdô- és végpontja között. Mivel sem a fiatalok élete, sem pedig az ôket körülvevô környezet nem változik - de még a megszokott, évszakok közti természeti alakulás is alig észrevehetô -, a mozdulatlanság látszata egyre inkább fokozódik. Úgy vélem, hogy a hagyományos filmi idôkezelési és az idô múlását érzékeltetố technikák kihagyása a háború utáni állapot kimerevítését, a pillanat állandósítását eredményezi. Ez a fajta temporális stagnálás szintén megragadható fotóelméleti szempontból: a fényképezés kimerevíti az idốt, a megdermedt mozdulatok pedig immár egy befejezett korszak képének részévé válnak. „Mihelyt rögzíti a fényérzékeny felület a pillanatot, az már egy letûnt múlt része. (...) Az idô elvégezte könyörtelen munkáját: a kép, ami megmarad, egy befejezett pillanat képe" ${ }^{[16]}$ - írja Jean A. Keim a fényképezés és a halál kapcsolatáról.

Az In The Shadow of War felvételeit azonban nem szemlélhetjük úgy, mint egy hagyományos albumot, amelybe az idô lineáris elôrehaladásának megfelelôen kerülnek bele a fényképek. Csak a 
körkörös mozgásról és az ebból fakadó mobilitás hiányáról kapunk újabb és újabb beállításokat, de nem mutathatunk rá egyik képre sem azzal a kijelentéssel, hogy ez már a múlt, vagy azzal, hogy a film története „továbbhaladt”. A film címe is ebból a szempontból közelíthetô meg: a háború árnyéka az 1995-ben lezárt konfliktus óta egyre hosszabbra nyúlik, ám ennek takarásában szinte észrevehetetlen az azóta eltelt idő. A keretek közé szorult szereplők mindennapjainak „fényképei”, s azok idôtlensége Christian Metz a fényképek temporalitásáról tett állításai felól is olvashatók. Bazin-hez és Barthes-hoz hasonlóan Metz is különbséget tesz ontológiai értelemben a fotó és a film között: az egyik legfontosabb differenciát a lexis tér-idô mértékében látja. (A lexis fogalmát Luis Hjelmslevtôl veszi át: a kifejezés egy bizonyos mértéket jelöl a befogadás szempontjából, pl. a szobrászatban a szobor, a zenében a darab a lexis.) A fotografikus lexis - azaz a téglalap alakú állókép - temporalitását tekintve alapvetôen különbözik a filmi lexistôl: míg utóbbinak meghatározott befogadási ideje van, addig az elóbbinek nincsen pontosan behatárolható idôtartománya, idôbeli mérete - hanem a szabadon változtatható. ${ }^{[17]}$

Ez esetben találó lehet a „filmszakadás” analógiával élni: a külvilág számára lezárultnak tûnő balkáni háború sokak számára még korántsem fejezôdött be. A háború látszólagos végének pillanata kitágult, a filmtekercs elszakadt, és megdermedt állóképként folytatódott: a balkáni konfliktus utóhatásai így pedig a film szereplóinek megbénult életén tapasztalhatók. ${ }^{[18]} \mathrm{A}$ hiány érzete éppen ezért fokozódik a film során. Nem arról van szó, hogy a háború tabunak számítana, vagy a szereplôk ne beszélnének az ôket ért sérelmekrôl, épp ellenkezőleg: annak ellenére, hogy verbalizálják a problémáikat, a háború okozta veszteségeiket, még sincsenek lehetôségeik és eszközeik arra, hogy feldolgozzák azokat. Igen meghatározó az is, hogy a film szereplôi alig idéznek fel emlékeket. A legtöbb múltbéli háborús eseményt Magdalena apja emlegeti fel szúkszavúan, de a fiatalok - néhány jelenetet leszámítva -- szinte csak a balkáni konfliktus ôket ért, illetve szüleiken tapasztalt hatásairól beszélnek. Mivel a fiatalok mind a boszniai háború végén születtek, primer emlékeik alig vannak, az öröklött háborús tapasztalat feldolgozásával pedig egyedül nem tudnak megküzdeni. Ez a fajta emlékezési mechanizmus, az emlékek hiányának problémája összecseng Maurice Halbwachs kollektív emlékezetról tett állításaival - a szociológus a különbözô múltbéli események felidézéséhez elengedhetetlennek tartja egy adott közösséghez, csoporthoz való tartozás meglétét.

Az egyén elméjében felbukkanó emlék csak akkor válik érthetôvé, ha a megfelelố csoport gondolatvilágában helyezzük el. [M]inden benyomásról és eseményrốl [...] csak annyiban ôrzünk tartós emléket, amennyiben reflektálunk rá, elgondolkodtunk rajta, vagyis amennyiben a társadalmi közegból származó gondolatokhoz kapcsoltuk óket. Csak úgy tudunk elgondolkodni a múltunk eseményein, ha okfejtéseket végzünk velük kapcsolatban, ez pedig azt jelenti, hogy egyazon gondolatrendszerbe fúzzük saját magunk és környezetünk meglátásait, miközben abban, ami velünk történik, olyan egyedi történéseket látunk, amelyeknek a közösség számára megnyilvánuló jelentôségére és súlyára állandóan emlékeztet bennünket a társadalmi gondolkodás. ${ }^{[19]}$ 
A múltbéli események ezen reflexív megközelítése összhangban áll az elôzőekben ismertetett foucault-i gondolatokkal, miszerint csak úgy tudjuk megélt jelenünket hozzáférhetôbbé tenni saját magunk számára, ha a múltat is elgondoljuk. Ennek hiányában azonban a filmben látható, magára hagyott boszniai csoport a háborús múlt kitágított, állandósult pillanatában, keretek közé szorítva éli mindennapjait. [20]

A hiány érzete különösen felerôsödik abban az esetben, ha figyelembe vesszük az In The Shadow of War külsô, kereten kívüli tereit - fontos, hogy ebben az esetben nem technikai értelemben vett filmként, hanem ontológiai szempontból fényképként közelítsünk az alkotáshoz. E nem látható, külsô keret terét [off-frame space] Christian Metz a film és a fotó esetében is megvizsgálja, s jellegüket tekintve különíti el egymástól ôket: míg a film esetében e térmeghatározás szubsztanciális, addig a fotóval kapcsolatban sokkal nehezebben megfogható. Barthes-hoz hasonlóan Metz állítása is az, hogy ha valaki a fényképen a kereten kívül helyezkedik el, sosem fog belépni a keretbe, így a kereten-kívüliség is felfogható egyfajta halálként. A nézőnek nincsen empirikus tudása a kereten kívüli eseményekrôl, mégis megpróbálja elképzelni azokat, kitölteni ezt a fajta hiányt. ${ }^{[21]}$ (Barthes számára csak a punctum-szerú képek azok, amelyek e fantáziálást elindíthatják, Metz számára nem kizárólagos e kategória.) E szempont az elemzett filmben igen érdekesen érvényesül. A kezdôjelenetekben csak a fiatalok elbeszéléseiből hallunk a szüleikrôl, a felnôttekkel viszont nem találkozunk, vizuálisan nem reprezentálódnak, tehát nézóként megpróbáljuk mentálisan pótolni az így keletkezett képi ûrt, a kereten kívül elhelyezkedô szülók alakját. Amikor a film különbözố pontjain feltûnnek a kereten belüli térben az apaként és anyaként megnevezett emberek - Magdalena háborúban megtört, rideg apja; Ilija anyja, aki a kamerának hátat fordítva, köszönés nélkül bemenekül a házba fia elöl; Ante apja, aki évente három napra látja gyermekét, és a fiú úgy nyilatkozik késóbb, hogy az év 360 napján nincsen apja; és végül Elvis, aki anyjának sírját, egy földhalmot mutat be, amikor a szülók reprezentálására kerül a sor -, a nézố hiányérzete nem csökken, sôt, még inkább elmélyül. Azáltal, hogy besétálnak a keretbe, és a nézô szembesül azzal, hogy nem tudják betölteni szülôi szerepüket a fiatalok életében, még inkább érzékelhetố az a fajta hiány, amely a négy szereplô mindennapjait megszervezi. ${ }^{[22]}$ 


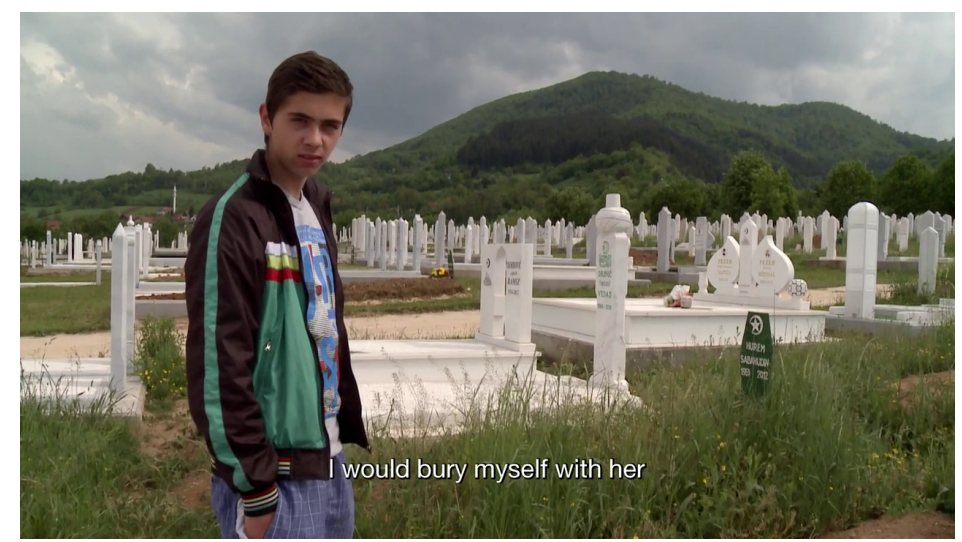

Elvis a zenicai temetöben. In The Shadow of War (Georgia

Scott-Sophia Scott, 2014)

\section{Képeslapok helyett emlékképeket! - A vizualitás visszaszorítása és az ábrázolhatóság problémája}

A keret szabta határokon túl érdemes a kereten belüli tartalomra, pontosabban annak vizuális megjelenítésére, a vizualitás visszaszorításának kérdésére is koncentrálni, ennélfogva a hiány problémáját egy harmadik szempontból megvizsgálni: a trauma ábrázolhatóságának/ ábrázolhatatlanságának aspektusából. Paula Rabinowitz politikai dokumentumfilmekról szóló kötetében felveti annak kérdését, hogy vajon van-e még valami, amit nem láttunk a dokumentumfilmekben, illetve képesek-e ma még, vagy képesek voltak-e valaha ezek az alkotások tömegeket mozgósítani? Rabinowitz amellett érvel, hogy mára mintha túltelítôdtünk volna a dokumentumfilmes képekkel, és úgy tûnik, már mindent láttunk, a közönséget nem lehet meglepni. ${ }^{[23]}$ A teoretikus Claude Lanzmann Shoah címú filmjét említi példaként a vizualitás visszaszorításával kapcsolatban, amelyben a rendező visszautasította a koncentrációs táborokról készült archív felvételek használatát, és helyette inkább egy másik irányt választott: az emlékezet képzeletbeli visszaszerzését a verbalitáson keresztül. ${ }^{[24]}$ Ami ebből a szempontból elsőre az In The Shadow of War esetében a nézônek feltûnhet, hogy a háború utóhatásairól szóló filmben egyetlen „bizonyító erejû” archív felvételt sem látunk a balkáni konfliktusról, hanem a rendezôk kizárólag a jelen eseményeit rögzítik. (Egy kivétel látható csak: Ante apjának 2004-ben történt bírósági tárgyalásáról néhány képkockát bevágnak utólag az alkotók, de az elôzôek értelmében tulajdonképpen ez is háborús utóhatásként fogható fel - csakúgy, mint a több mint egy évtizeddel késôbbi felvételek.)

A vizuális reprezentáció ilyen jellegú visszaszorításának, úgy vélem, kétféle motivációja is lehetett. Egyrészt az a felismerés, amelyet W. J. T. Mitchell a „kimondhatatlan és elképzelhetetlen” retorikai trópusokkal ír le, amelyek „egyidejűleg idézik fel és haladják meg a nyelv és a leírás, a diskurzus és a bemutatás korlátait." ${ }^{[25]}$ A kimondhatatlan és az elképzelhetetlen közti különbség a beszédre való képesség hiánya és a beszéd visszautasítása között található, Mitchell pedig arra hívja fel a figyelmet, hogy - habár lehetetlen vállalkozásnak tûnik, mégis - szüntelenül szavakkal és képekkel 
akarunk ábrázolni traumatikus eseményeket: ,javíthatatlanul ragaszkodunk ahhoz, hogy beszéljünk róla, ábrázoljuk, hogy egyre elevenebb és prózaibb módon próbáljuk visszaadni." ${ }^{26]} \mathrm{A}$ két trópus közti differencia elsôsorban a saussure-i jelelmélet, a jelölő és a jelölt kapcsolata felôl ragadható meg. Az elképzelhetetlen mint hiányzó jelölt kap szerepet: azt a dolgot jelöli, amelyet nem tudunk elképzelni és a képzelóerônk sem tudja mentális kép formájában megjeleníteni. A kimondhatatlan viszont jelölóként van jelen: „felszíni jel, kifejezés vagy olvasható jelzés, amelyet el kell hallgattatni, és ki kell törölni." ${ }^{27]}$ Mitchell a jelöltet a trauma lenyomataként azonosítja, a jelölôt pedig önkényes, konvencionális hangként - ez mindig annak a hiányzó oknak lesz a jelzője, amely az emberi emlékezetben valamilyen mentális nyomot hagyott. Meglátásom szerint abban a döntésben, hogy az In The Shadow of Warban nem használtak archív háborús felvételeket, egyrészt e mitchelli felismerés játszhatott szerepet: attól még, hogy a generikus eseményról látunk felvételeket, nem jutunk közelebb a szereplők tapasztalataihoz, hiszen az csak önkényes jelölóje volna az általuk megélt borzalmaknak.

Másrészt viszont - az elôzố szemponttal némileg ellentétben - olyan hiányérzetrôl, hiányokról van szó a filmben, amelyek nem ragadhatók meg sem képileg, sem nyelvileg: mivel a fiatalok esetében épp hiányzó emlékekrôl van szó, elôbb be kell ôket avatni a háborús tapasztalatot ôrzók körébe és termékenyen feldolgozni a balkáni konfliktus eseményét, hiszen csak így válhatnak ók is a Marienne Hirsch-i értelemben vett utóemlékezókké ${ }^{[28]}$ A hiány alakzatainak filmbeli jelölöit, s ennek problémáját az alkotók képileg összetett módon oldják meg. Az egyik legszemléletesebb példája ennek az Elvis hegeirôl készült gyakori premier plánok. A fiú sokszor sebesíti meg magát különbözô késekkel, karjai szinte teljes felületén mély, fehér hegek láthatók. Magát a megsebzést sosem látjuk, csak annak eredményét: e látványban manifesztálódik Elvis magánya, kétségbeesése és depressziója. A vizuális reprezentáció a sebek megmutatásánál megtorpan, ám e megoldás egyben a traumakoncepció két jelentésének érdekes vegyítése is: e képsorok pontosan referálnak a seb és a trauma évszázados összefüggéseire.

Cathy Caruth Unclaimed Experience címú kötetében ír arról, hogy a görög trauma szó eredetileg egy testi sérülést jelölt, a késóbbi korokban, majd a freudiánus szóhasználatban már nem a testen található, hanem a tudatban fellelhető sebet jelentette. Pszichoanalitikus értelemben azonban „a tudat sérülése" nem a testihez hasonló, egyszerúen és gyorsan begyógyuló folyamat, hanem egy olyan esemény eredménye, amely túl hamar és váratlanul következett be, így pedig a tudat nem tudott felkészülni rá. ${ }^{[29]}$ Ami tehát ebból a szempontból fontos számunkra, hogy a trauma tulajdonképpen a seb története: ez az, ami ösztökél bennünket egy olyan „valóság” megismerésére, amely eddig nem volt számunkra elérhetô. Ez pedig nem csak azt jelenti, hogy valami tudottá válik számunkra, hanem azt is, hogy valami mindig szükségszerúen a felszín alatt fog maradni. Ha a pszichoanalitikus megközelítést bővítjük a fotóelméleti aspektussal és e szempontból közelítünk Elvis hegeihez, fontos analógiát találunk a hiány és az örök idôkre szóló sebek kapcsolatában. Az édesanyja elvesztése miatt maga a fiú is meg szeretne halni („Ha tehetném, magamat is mellé temetném”), az anya miatt érzett hiány pedig a karján lévố sebekben manifesztálódik. [30] 


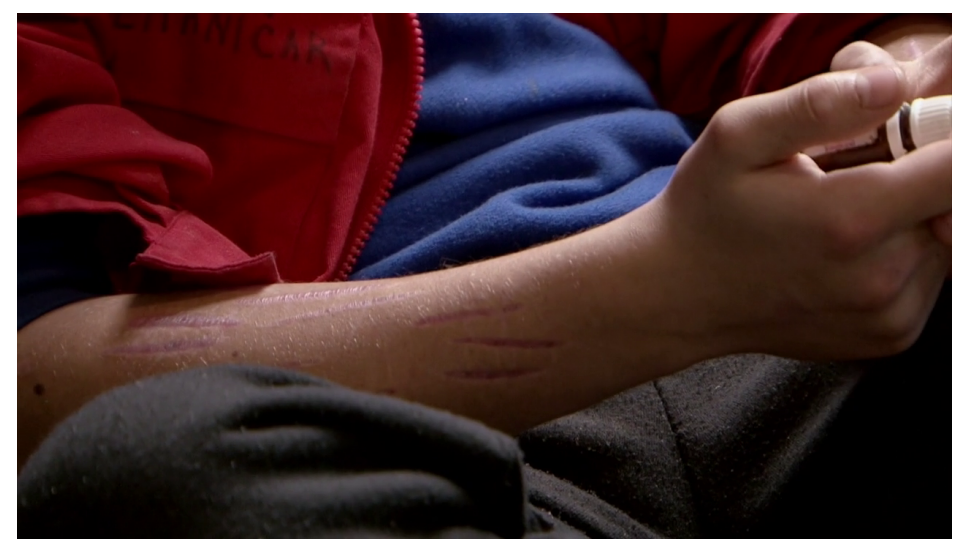

In The Shadow of War (Georgia Scott-Sophia Scott, 2014)

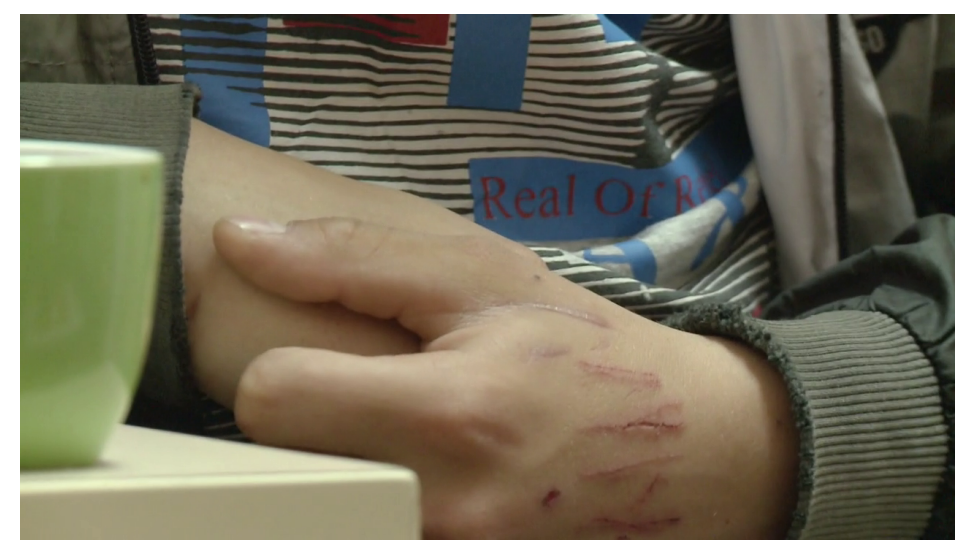

In The Shadow of War (Georgia Scott-Sophia Scott, 2014)

A testére vésett nyomok Elvis számára ugyanúgy múködhetnek, mint a fényképeken jelenlévô alakok, akik - Fritz Kempe interpretációjában - egy véglegesen távollévô imaginárius jelenlétének jelei.[31] Így a sebek közelije tulajdonképpen a fénykép funkcióját tölti be a fiú esetében: a sebek által anyja emlékét ôrzi, és arra tesz kísérletet, hogy valamiképpen még jelenlévô maradjon számára. ${ }^{[32]}$ Mindez úgy vélem, nagyon érzékletes reprezentációja a Mitchell-féle probléma tematizálásának: a sebek csak önkényes jelölókként funkcionálhatnak, a trauma pedig emiatt ábrázolhatatlanná válik a filmben. ${ }^{[33]}$

Végül érdemes feltenni azt a kérdést, mi lehet e dokumentumfilmnek a társadalmi tétje. Tanulmányom elején a nevelôotthon dolgozójának szavait idéztem, melyeken keresztül a háború alatt és után született fiatalokat egy elveszett generáció részének tekintette. A rendezôk egyik implicit célja e láthatatlan gyermekek és fiatalok sokaságának láthatóvá tétele: nem csak e korosztály reprezentálása, hanem a posztháborús állapotokra való reflexió és a köztudatban élô, háborút követố békés idôszak illúziójának eltörlése. Az emlékezet a fotóhoz képest mindig hézagos jellegú - írja Siegfried Kracauer -, ezért különbséget kell tennünk a fényképek és az emlékképek között. Míg az első az adottat „mint térbeli (és időbeli) kontinuumot ragadja meg”, addig az emlékképek a pillanatot „úgy ôrzik, mint ami jelent valamit."[34] Visy Beatrix interpretációjában a fénykép tulajdonképpen az emlékezet eltörlését eredményezheti, mivel az emlékkép helyén a fotó fog állni, és ezáltal sokkal inkább a materiális, éles képekre fogunk emlékezni, kevésbé az absztrakt, jelentésekkel telített emlékképekre. „[A] rögzített látvány szemlélése a keret nélküli, 
gomolygó, képlékeny emlékképet törli el, akárhányszor a képekre nézünk, [...] a kiélesített pillanat az emlékkép helyébe nyomul."[35]

Úgy vélem, az In The Shadow of War valódi, társadalmi szempontból releváns tétje e fotóelméleti mozzanatban ragadható meg, és így már nem (csak) a szereplôk helyzetét mutatja be, hanem a közönséghez, a nem boszniai nézókhöz szól. Mára már Boszniában is meghatározó a traumaipar: a turisztikai látványossággá lett posztháborús övezetben a szuveníres bódék lövedéket mintázó kulcstartókat, az ostromlott város lakói által létrehozott, a mesterlövészek pozícióját jelölô, túlélô térképek replikáit és a turista fotók állandó motívumaként megjelenô, az Öreg híd lerombolását és újjáépítését ábrázoló képeslapot árulnak.

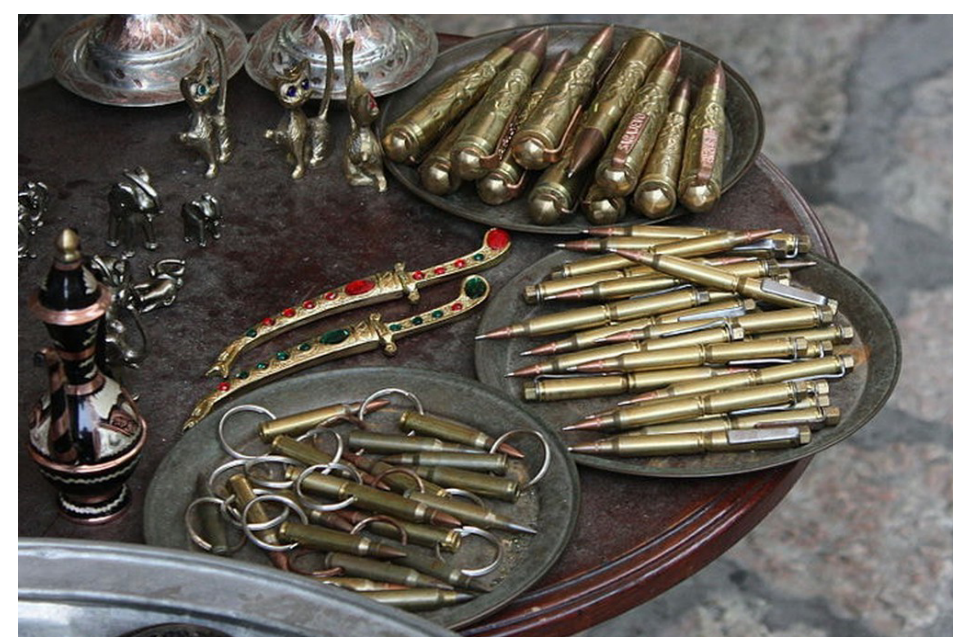

Az utcán talált lövedékek felhasználásával készült kulcstartók.

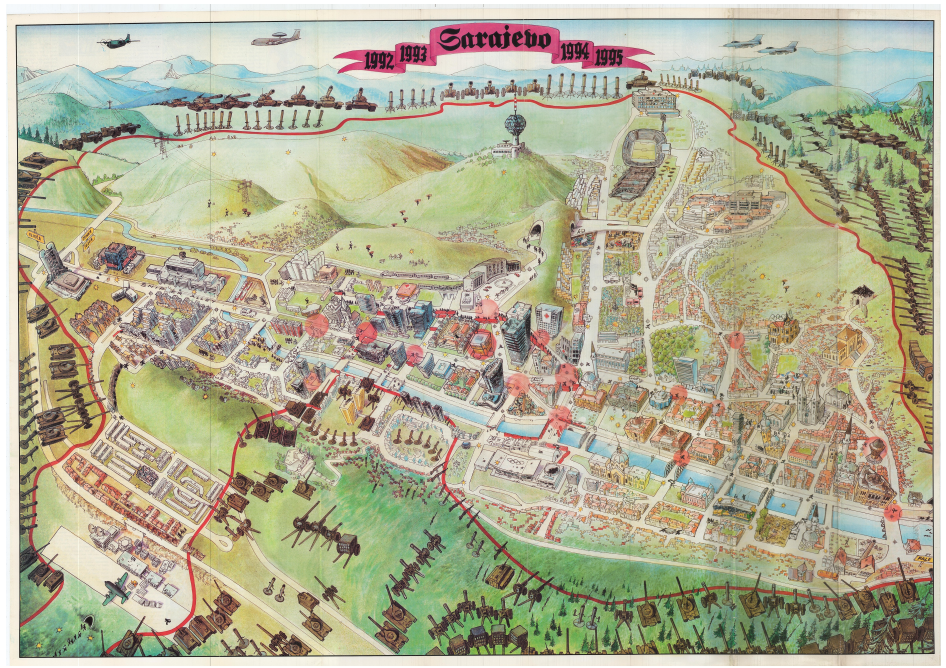

Survival Map 1992-1996 (Sarajevo, 1996)

A film erre reflektálva megrázó háborús felvételek használata nélkül hívja fel a figyelmet arra, hogy e szuvenírcikkek csak a megélt jelen részei lesznek, ha nyaralási úti célként, egzotikusnak számító háborús látnivalóként tekintünk Kelet-Európa egyik legvéresebb konfliktusának helyszínére. „Képeslapok helyett emlékképeket szerezzünk!” - összegezhetnénk a film alapján. Mindaddig, amíg nem reflektálunk a múltbéli eseményekre, keretek közé szorulva, újabb és újabb 
kompozíciókba rendeződve várakozunk az éppen exponáló fényképezőgép elôttt.

1. Barthes, Roland: Világoskamra. Jegyzetek a fotográfiáról. Ford. Ferch Magda. Budapest, Európa Könyvkiadó, 1985. 108.

2. Foucault, Michel: Más terekrôl. Heterotópiák. ExIndex, 2004. 08. 09. URL: http://exindex.hu/index.php?page=3\&id=253 (Letöltés ideje: 2020. 07. 10.) (Ford. Erhardt Miklós)

3. Foucault: i. m.

4. Foucault: i. m.

5. Kiss Noémi: Fekete-fehér. Tanulmányok a fotográfia és az irodalom kapcsolatáról. Miskolc, Múút-könyvek, 2011. 31.

6. Foucault: i. m. E megközelítés analógnak hat Foucault előbb idézett szövegének múzeum-definíciójával, amelynek lényege, hogy mint általános archívum, a múzeumban minden idő, kor, forma, ízlés egy helyre koncentrálódik: az idô végtelen felhalomázásáról beszélhetünk egyetlen, mozdulatlan helyen.

7. Takács Ádám: Az idô nyomai. Michel Foucault és a történelem problémája. Budapest, Kijárat Kiadó, 2018. 26.

8. Strausz László: Realizmus és modernizmus között. Hezitáció és az új román film értelmezésének keretei. Metropolis, 2016/2. 12.

9. Michel de Certeau a teret a mozgó dolgok keresztezôdéseként, illetve mint hatást értelmezi, amely sosem stabil vagy egyértelmú: „a tér a gyakorlatba vont hely”. (de Certeau, Michel: A cselekvés múvészete. A mindennapok leleménye I. Ford. Sajó Sándor-Szolláth Dávid-Z. Varga Zoltán. Budapest, Kijárat Kiadó, 2010. 141.)

10. Jameson Michelangelo Antonioni Napfogyatkozás (L'eclisse. 1962) címú filmjének záró képsorait elemzi, amelyben azt a helyszínt látjuk, ahova a két szereplő randevút beszélt meg, ám ók maguk nem érkeznek meg oda. A teoretikus a jelenetben látható útkeresztezôdést nevezi degradált térnek, amely megidézi az esemény helyét, „egy körülhatárolt teret, amelyben történhet valami, és amely elött az ember szertartásosan várakozik”. Amikor azonban ez az esemény elmarad (azaz a Napfogyatkozás esetében a két szereplô találkozása), ez a hely visszasüllyed térré, amelyben nem történik semmi, csak a történés eshetôségét érezzük. Jameson, Fredric: A posztmodern, avagy a kései kapitalizmus kulturális logikája. Ford. Dudik Annamária Éva. Budapest, Noran Libro, 2010. 109.

11. Bôvebben lásd: Faragó Kornélia: Szemléleti terek, helyzeti reprezentációk. A térgondolkodás dominanciájáról. In uô: Idôk, terek, intenzitások. Teoretikus tanulmányok, szövegértelmezések. Újvidék, Forum Könyvkiadó, 2016. 7-17.

12. Bazin, André: A fénykép ontológiája. In uô: Mi a film? Esszék, tanulmányok. Ford. Baróti Dezsô. Budapest, Osiris Kiadó, 2002. 16-23. 16.

13. Bazin, André: Festészet és film. In Mi a film? Esszék, tanulmányok. Ford. Baróti Dezsô. Budapest, Osiris Kiadó, 2002. 146-152. 148.

14. Barthes: i. m. 65.

15. Uo. 65-66.

16. Keim, A. Jean: A fényképezés és a halál. Ford. Jávor Anna. In Fotóelméleti szöveggyújtemény. Szerk. Bán András-Beke László. Budapest, Enciklopédia Kiadó, 1997. 147-160. 150.

17. Mivel alapvetôen a nézôtôl függ, mennyi ideig tanulmányozza az adott képet, Metz a késôbbiekben éppen ezért elemzi a fotót a fétis szempontjából. Metz, Christian: Photography and Fetish. October, 1985. ôsz. 81.

18. Különösen kifejező ebből a szempontból Magdalena film eleji megjegyzése: „Minden, ami eddigi életem során történt velem, annak a következménye, hogy az apám megjárta a háborút. Nem tudta, mit kezdjen a poszttraumás stressz szindrómájával - a háború sebet ejtett rajta, így rajtam keresztül próbálta ezt 
feldolgozni."

19. Halbwachs, Maurice: Az emlékezet társadalmi keretei. Ford. Sujtó László. Budapest, Atlantisz Kiadó, 2018. 189.

20. Habár a jelen tanulmány vállalásán és vizsgálati szempontjain túlmutat, a „bekeretezettség” érzetének kérdése további érdekes irányokat vethet fel. Kaja Silverman a tekintet és a kamera problematikájával kapcsolatban említi, hogy mi magunk is sokszor találhatjuk magunkat fényképszerú szituációkban. „Amikor érzékeljük, hogy a társadalmi tekintet ránk fókuszál, akkor »fényképszerúen « bekeretezettnek érezzük magunkat. Ám ennek a fordítottja is igaz: amikor valódi kamerát irányítanak ránk, akkor szubjektíve megformáltnak érezzük magunkat, mintha az ennek eredményeként megszületô kép bármiképp meghatározhatná, hogy »kik« vagyunk.” (Silverman, Kaja: A tekintet. Ford. Szemzó Hanna. Metropolis, 1999/2, 32.)

21. Metz: i. m. 86-87.

22. Ebből a szempontból is érdekes Metz megközelítése a képen belüli hiányzó kapcsán. Ez a kifejezés a filmben a látott hiány és a közeli jelenlét közti eltolódást jelöli; jelen elemzésben ez különösen a dokumentumfilm vizuális dramaturgiája esetében releváns. (Metz: i. m. 87.)

23. Rabinowitz, Paula: They Must Be Represented. The Politics of Documentary. London-New York, Verso Books, 1994. 15. A teoretikus hatástörténeti szempontból azt az 1991-ben készült, nyolcperces videót elemzi, amelyen Los Angeles-i rendôrök egy csoportja Rodney Kinget bántalmazza brutálisan gyorshajtás és ittas vezetés miatt (Uo. 205-215). A videó gyorsan elterjedt, és igen széles nyilvánossághoz jutott el: az 1992-ben kezdôdô antirasszista tüntetések egyik kiváltó oka az volt, hogy a tárgyalások után a bíróság négy rendôrt is felmentett az elôzetes vádak alól. Rodney Kinggel ellentétben George Floyd 2020. május 25-én nem élte túl a vele szemben alkalmazott rendôri brutalitást: a két eset megrázó hasonlósága mellett mediális közvetítettsége révén tömegeket mozgósított, a videók hatástörténetének vizsgálata további dokumentumfilmes kutatások alapjául is szolgálhat.

24. Alain Resnais a Szerelmem, Hiroshima (Hiroshima mon amour. 1959) címú fikciós filmjének elkészítése elôtt más múfajban, dokumentumfilmben is gondolkodott, de végül a Lanzmannéhoz hasonló indokok miatt adta fel tervét: úgy gondolta, hogy a Hiroshimáról készült direkt, archív felvételek nem tartalmazzák a tragikus esemény sajátlagosságát. (Caruth, Cathy: Unclaimed Experience. Trauma, Narrative and History. Baltimore, The Johns Hopkins University Press, 1996. 66.)

25. Mitchell, W. J. T.: A kimondhatatlan és az elképzelhetetlen. Ford. Horváth Gyöngyvér. In A képek politikája. W. J. T. Mitchell válogatott írásai. Szerk. Szőnyi György Endre-Szauter Dóra, Szeged, JATE Press, 2008. 267-284. 269.

26. Uo. 271.

27. Uo. 273.

28. Hirsch interpretációjában a postmemory olyan hagyomány, amely közvetlen tapasztalat híján van, azaz az utódnemzedéknek - aki még az adott esemény idején nem élt - nincs közvetlen hozzáférése a szóban forgó korszakhoz. Utóemlékezetnek nevezi azt a „kulturális vagy kollektív traumát túlélók gyermekeinek a szüleik tapasztalatához füzôdő viszonyát, amely tapasztalatokra a leszármazottak csupán a növekedésüket végigkísérô elbeszélésekben és képeken keresztül »emlékeznek«, miközben ezek mégis olyan erôsek és monumentálisak, hogy saját emlékeket is képesek generálni” (Hirsch, Marianne: Túlélô képek. Holokausztfotók és az utóemlékezet munkája. Ford. Pintér Ádám. In Transznacionális politika és a holokauszt emlékezete. Szerk. Szász Anna Lujza-Zombory Máté. Budapest, Befejezetlen Múlt Alapítvány, 2014. 85-213. 190). Hirsch az utóemlékezetet rendkívül erös kapocsnak tartja éppen azért, mert az egyén nem saját élményanyagra, hanem örökölt ábrázolásokra támaszkodik.

29. Caruth: i. m. 17-18. 
30. A seb mint metafora a film több pontján is felbukkan még: Ilija nevelője a háború idején született, szülők nélkül felnôtt fiú esetében állítja, hogy mindez „sebet ejthetett” rajta, Magdalena apja és annak háborús tevékenysége esetében él a „örök sebek maradtak rajta” hasonlattal, Elvis pedig apjáról csak annyi emléket óriz, hogy „az egész testét sebek lepték el”, amikor hazatért a frontról.

31. Fritz Kempe írását idézi Jean A Keim. (Keim: i. m. 149.) E megállapítással szorosan összefüggnek Christian Metz a fényképezés és a halál viszonyával kapcsolatban tett állításai. Az egyik legfontosabb közös pont az, hogy általában azokról ôrzünk fényképeket, akik már nincsenek velünk. De ez abban az esetben is releváns, ha az, akirôl a fénykép készült, még életben van, mivel a pillanat, amelyben lencsevégre kapták, már örökre eltûnt: az, akit lefotóztak, halott. Metz szerint a másik kapocs az, hogy a fotó, csakúgy, mint a halál, egy pillanatra elragadja a világból az objektumot egy másik világba, egy másfajta időbe. A fotográfia tulajdonképpen kivág egy részt, egy fragmentumot az adott referensból, amelyet egy hosszú, egy helyben folyó utazásra visz, és soha többé nem hozza vissza. (Metz: i. m. 84.)

32. Vö. Keim: i. m. 147-160.

33. Az önkényes jelölô problémája a film egyik leginkább megrázó jelenetében érthetô meg igazán, amikor Elvis bemutatja édesanyját a film stábjának. Ahelyett, hogy egy fényképet mutatna, kivezeti az operatôrt a temetôbe, és egy szegényes földhalomra rámutatva közli: „Ez az, ez az anyám.”

34. Kracauer, Siegfried: A fotográfia. Ford. Schulcz Katalin. In Fotóelméleti szöveggyüjtemény. Szerk. Bán András-Beke László. Budapest, Enciklopédia Kiadó, 1997. 137-146. 138.

35. Visy Beatrix: A fénykép tere. Ekphraszisz, nézőpont és határátlépés. Alföld, 2014/12. 105.

\section{Irodalomjegyzék}

- Barthes, Roland: Világoskamra. Jegyzetek a fotográfiáról. Ford. Ferch Magda. Budapest, Európa Könyvkiadó, 1985.

- Bazin, André: A fénykép ontológiája. In uô: Mi a film? Esszék, tanulmányok. Ford. Baróti Dezsô. Budapest, Osiris Kiadó, 2002. 16-23. 16.

- Bazin, André: Festészet és film. In uô: Mi a film? Esszék, tanulmányok. Ford. Baróti Dezsó. Budapest, Osiris Kiadó, 2002. 146-152.

- Caruth, Cathy: Unclaimed Experience. Trauma, Narrative and History. Baltimore, The Johns Hopkins University Press, 1996.

- De Certeau, Michel: A cselekvés múvészete. A mindennapok leleménye I. Ford. Sajó Sándor-Szolláth Dávid-Z. Varga Zoltán. Budapest, Kijárat Kiadó, 2010.

- Faragó Kornélia: Szemléleti terek, helyzeti reprezentációk. A térgondolkodás dominanciájáról. In uô: Idók, terek, intenzitások. Teoretikus tanulmányok, szövegértelmezések. Újvidék, Forum Könyvkiadó, 2016. 7-17. https://doi.org/10.17649/TET.31.1.2839

- Foucault, Michel: Más terekról. Heterotópiák. ExIndex, 2004. 08. 09. URL: http://exindex.hu/index.php?page=3\&id=253 (Letöltés ideje: 2020. 07. 10.) (Ford. Erhardt Miklós)

- Halbwachs, Maurice: Az emlékezet társadalmi keretei. Ford. Sujtó László. Budapest, Atlantisz Kiadó, 2018.

- Hirsch, Marianne: Túlélő képek. Holokausztfotók és az utóemlékezet munkája. Ford. Pintér Ádám. In Transznacionális politika és a holokauszt emlékezete. Szerk. Szász Anna Lujza-Zombory Máté. Budapest, Befejezetlen Múlt Alapítvány, 2014. 85-213. 
- Jameson, Fredric: A posztmodern, avagy a kései kapitalizmus kulturális logikája. Ford. Dudik Annamária Éva. Budapest, Noran Libro, 2010.

- Keim, Jean A.: A fényképezés és a halál. Ford. Jávor Anna. In Fotóelméleti szöveggyújtemény. Szerk. Bán András-Beke László. Budapest, Enciklopédia Kiadó, 1997. 147-160.

- Kiss Noémi: Fekete-fehér. Tanulmányok a fotográfia és az irodalom kapcsolatáról. Miskolc, Mũútkönyvek, 2011.

- Kracauer, Siegfried: A fotográfia. Ford. Schulcz Katalin. In Fotóelméleti szöveggyüjtemény. Szerk. Bán András-Beke László. Budapest, Enciklopédia Kiadó, 1997. 137-146.

- Metz, Christian: Photography and Fetish. October, 1985. ôsz. https://doi.org/10.2307/778490

- Mitchell, W. J. T.: A kimondhatatlan és az elképzelhetetlen. Ford. Horváth Gyöngyvér. In A képek politikája. W. J. T. Mitchell válogatott írásai. Szerk. Szőnyi György Endre-Szauter Dóra, Szeged, JATE Press, 2008. 267-284.

- Rabinowitz, Paula: They Must Be Represented. The Politics of Documentary. London-New York, Verso Books, 1994.

- Silverman, Kaja: A tekintet. Ford. Szemzó Hanna. Metropolis, 1999/2. 24-33.

- Strausz László: Realizmus és modernizmus között. Hezitáció és az új román film értelmezésének keretei. Metropolis, 2016/2.

- Takács Ádám: Az idô nyomai. Michel Foucault és a történelem problémája. Budapest, Kijárat Kiadó, 2018.

- Visy Beatrix: A fénykép tere. Ekphraszisz, nézôpont és határátlépés. Alföld, 2014/12.

\section{Filmográfia}

- In The Shadow of War (Georgia Scott-Sophia Scott, 2014)

- Shoah (Claude Lanzmann,1985)

- Szerelmem, Hiroshima (Hiroshima mon amour. Alain Resnais, 1959)

- Napfogyatkozás (L'eclisse. Michelangelo Antonioni, 1962) 
(C) Apertúra, 2020. tavasz | www.apertura.hu

webcím: https://www.apertura.hu/2020/tavasz/simor-a-poszthaborus-pillanat-hosszu-expoziciojaa-boszniai-haboru-utohatasainak-ter-es-fotoelmeleti-megkozelitese/

https://doi.org/10.31176/apertura.2019.15.3.4

$$
\text { (2)opertúro }
$$

